\title{
Critical Limb Ischaemia in Adult Human Skeletal Muscle Increases Satellite Cell Proliferation but Not Differentiation
}

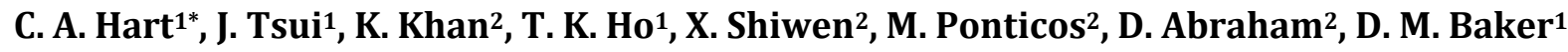 \\ ${ }^{1}$ Department of Vascular Surgery, Royal Free Hospital, London, UK \\ ${ }^{2}$ Department of Rheumatology, Royal Free Hospital, London, UK \\ Email: ${ }^{*}$ c.hart@doctors.net.uk
}

Received 19 December 2014; accepted 29 April 2015; published 5 May 2015

Copyright (C 2015 by authors and Scientific Research Publishing Inc.

This work is licensed under the Creative Commons Attribution International License (CC BY).

http://creativecommons.org/licenses/by/4.0/

(c) (i) Open Access

\section{Abstract}

Critical Limb Ischaemia (CLI) is defined as the presence of rest pain, ulcers and/or gangrene in a limb for over 2 weeks. Associated exercise intolerance is caused by muscle fibre atrophy, fibrofatty infiltration, nerve dysfunction, mitochondrial damage and myofibril disorder. We aimed to determine the behaviour of satellite cells, responsible for the repair and regeneration of damaged muscle, in repairing the damage caused to critically ischaemic adult human skeletal muscle. CD34, pax7 and MyoD are all markers of satellite cells at different stages of the cell cycle and allow for an assessment of their number and activity in ischaemia. Local ethical committee approval and informed consent was obtained. Samples of harvested gastrocnemius muscle of patients undergoing major perigenicular amputation for CLI $(n=10)$ were analysed and compared to a control group undergoing coronary artery bypass grafting $(n=10)$. Using immunohistochemistry, the expression of pax7, CD34 and MyoD was assessed in five sequential blinded randomly generated fields. Statistical testing of the data collected was made via the Mann Whitney $U$ test. Protein electrophoresis was used to confirm overall protein expression of the satellite cell markers. There was a significant increase in the number of satellite cells observed in CLI muscle sections as demonstrated by the expression of pax7 $(2.4 \times$ fold $p<0.0001)$. CD34 expressing Haematopoietic Stem Cells (HSCs) and satellite cells were also more abundant, with a $2 \times$ fold increase observed $(p<0.0001)$ whilst those cells expressing both $\mathrm{CD} 34$ and pax7 and identified as quiescent satellite cells, were significantly greater in number in the CLI samples $(2.9 \times$ fold $p<0.0001)$, confirmed via immunohistochemistry and protein electrophoresis. There was a significant decrease in the expression of MyoD positive or activated satellite cells $(p<0.0001)$. This indicates an increase in the proliferation of the satellite cell population as a response to CLI but less active cells are observed.

\footnotetext{
${ }^{*}$ Corresponding author.
} 


\section{Keywords}

\section{Muscle, Stem Cells, Satellite Cells, Muscle Progenitor Cells, Ischemia, Gastrocnemius}

\section{Background}

Critical Limb Ischaemia (CLI) is defined as the presence of symptomatic limb ischaemia of over 2 weeks duration usually caused by the presence of increasing intra luminal atheroma. It affects between $500-1000$ patients per million annually [1]. Atherosclerotic lesions reduce blood flow to large muscle end organs such as the thigh, calf and buttocks resulting in intermittent claudication on exercise. Prolonged reduction in blood flow, insufficient to deliver oxygen and nutrients also leads to lactic acidosis which in turn causes pain. Worsening atherosclerosis over a prolonged period causes rest pain in the extremities, relieved by gravity dependence and leading to patients sleeping overnight in chairs [2]. As plaques increasingly occlude the lumen of blood vessels over protracted periods of time, leading to tissue ulceration and ultimately gangrene [3].

Reduced exercise tolerance is caused by muscle fibre atrophy, fibro-fatty infiltration, nerve dysfunction, mitochondrial damage and myofibril disorder [4] [5]. An abundance of hybrid fibres, containing two myosin heavy chain phenotypes, has been observed in ischaemic tissue and indicates a dynamic process of fibre type repair, shift and myofibril regeneration in ischaemic muscle [6] [7].Type l fibres more resistant to hypoxia become predominant as type llx fibres are preferentially lost [4]-[6] [8]-[11]. The behaviour of satellite cells in critically ischaemic human skeletal muscle has not been well characterised, but these cells are responsible for the normal processes of repair and regeneration of damaged muscle including that caused by ischaemia [12]-[14]. Due to the deterioration in exercise tolerance seen in CLI, the morphological changes that take place indicate that satellite cells become dysfunctional or their regenerative capacity becomes overwhelmed.

Treatment of peripheral vascular disease requires a multi disciplinary approach involving the treatment of atherosclerosis itself, through the eradication of its risk factors and symptom control [1]. Therapeutic agents have had limited success in treating CLI and endovascular and open surgical procedures have poor outcomes [1] [2]. In treating ischaemic and perhaps other myopathies, it is possible that a therapeutic answer will lie with the administration of pro-myogenic agents administered to promote satellite cell function, grown in vitro and implanted into diseased muscle [14]-[16]. It has been shown that the precursors of these satellite cells, either derived from resident "side population cells" (SPCs) [17] [18] or circulating bone marrow derived haematopoietic stem cells (HSCs), are responsible for the myogenic process and may even have the potential to contribute to the processes of neurogenesis and angiogenesis [15] [16] [19]-[21]. Increased angiogenesis is certainly observed in ischaemic tissue, mediated through the global actions of Hypoxia-Inducible Factor (HIF)-1 $\alpha$ ). However the newly formed vessels do not reach maturity and are not fit for purpose, lacking a stable structure seen in established mature vessels [22]. Although satellite cells are by definition a myogenic precursor cell with their fate predetermined by the expression of pax7, they have been shown to be capable of regenerating cardiomyocytes in vitro and they may have the potential to form other mesodermal tissue [15] [16] [23].

Table 1 shows some commonly identified protein markers used to identify satellite cells at different stages in their life cycle. There is no single marker available to label all satellite cells, throughout the different stages of their cell cycle [24] but the majority of active, quiescent and proliferating satellite cells express pax7 [25]-[27] a paired-box transcription factor that has a molecular weight of $57 \mathrm{kDa}$ and is essential for the mitogenesis of these cells and the formation of either myogenic cells or rejuvenating the satellite cell pool [25] [28]-[30]. It is co-expressed with MyoD or myf-5 in activated satellite cells but is not present in those cells expressing myogenin [30] [31]. Quiescent satellite cells are pax7+/CD34+/MyoD-, whereas most active and proliferating cells express pax7+/CD34+/MyoD+ [24]-[30] [32]-[34].

This study aimed to show how by using some of the markers specified above, in an otherwise well matched sample of muscle biopsies, the presence of CLI affects satellite cell number and activity in vivo.

\section{Materials and Methods}

\subsection{Study Population}

Ten patients undergoing major lower limb amputation for critical limb ischaemia and ten age-matched patients 
undergoing coronary bypass grafting were recruited to this study after local ethical committee approval and informed consent was obtained. Patients with acute or acute on chronic ischaemia, auto-immune disease including vasculitides or tissue necrosis or oedema close to the site of biopsy were excluded from this study. Table 2 displays the demographics, risk factors for vascular disease and co-morbidities of the patients involved in this study.

\subsection{Tissue Collection and Processing}

The medial head of gastrocnemius [35] was biopsied in all cases and preserved immediately after harvesting by immersion either in liquid nitrogen or in formalin and later wax embedded. Paraffin embedded tissue was cut into $3 \mu \mathrm{m}$ slices perpendicular to the fibres using a microtome and eight consecutive slides were prepared in this way for picrosirius staining to assess orientation and identification of CD34, pax7 and myoD antibodies through standard ABC immunohistochemistry.

Five randomly chosen but sequential $400 \times 300 \mu \mathrm{ms}$ fields, following established protocols [5]-[15] [17]-[36] were identified on pre blinded slides and analysed using the Zeiss Axiosopp 4 light microscope at 200× magnification. Image capture was performed using an Olympus camera and JPEGS generated were stored to be analysed. The ABC method of immunohistochemistry was utilised with DAB chromagen and positive stains for each antibody were recorded in sequential slides and subjected to data analysis as outlined below. Table 3 illustrates the

Table 1. Satellite cell markers [14]. Some of the many markers expressed by satellite cells during different stages in their life cycle, with an indication of when these are expressed $(+)$ or absent $(-)$. In this present study, three protein markers (one cell surface protein and two transcription factors) were used for ease of analysis and because they complement each other in identifying the relevant cells as detailed later.

\begin{tabular}{|c|c|c|c|}
\hline Marker & Quiescent & Active & Proliferating \\
\hline \multicolumn{4}{|c|}{ Cell Surface } \\
\hline CD34 & + & + & - \\
\hline c-met & + & + & + \\
\hline M-cadherin & + & + & + \\
\hline MNF & + & + & + \\
\hline \multicolumn{4}{|c|}{ Transcription Factor } \\
\hline myf5 & - & + & + \\
\hline MyoD & - & + & + \\
\hline pax7 & + & + & + \\
\hline
\end{tabular}

Table 2. Patient demographics: There was no significant difference in the mean age of the two cohorts. (Mann Whitney U test; $\mathrm{p}<0.05$ inferred significance; 95\% CI). Patients were otherwise well matched for co-morbidities, risk factors as well as demographic characteristics.

\begin{tabular}{ccc}
\hline & Controls & Ischaemics \\
\hline Age & $73.20 \pm 1.965 \mathrm{~N}=10$ & $73.60 \pm 2.405 \mathrm{~N}=10^{\mathrm{ns}}$ \\
Sex & $9 \mathrm{M}: 1 \mathrm{~F}$ & 2 \\
Dyscrasias & 5 & $2 \mathrm{M}: 2 \mathrm{~F}$ \\
Diabetes & 10 & 6 \\
Heart Disease & 1 & 2 \\
CVA/ TIA & 10 & 8 \\
Cholesterol & 9 & 8 \\
Hypertension & 0 & 4 \\
PAD & 1 & 2 \\
Renal Disease & 1 & 8 \\
AAA & 8 & 9 \\
\hline
\end{tabular}


Table 3. Panel of antibodies used for satellite cell recognition.

\begin{tabular}{ccccccc}
\hline Antibody & Clone & Source & Species & Conc. & Pre-Treatment & Incubation \\
\hline CD34 & QBEnd-10 & Dako & Mouse monoclonal IgG & $1: 50$ & EDTA 20m & RT 1 hour \\
Pax7 & QC2152 & Aviva Systems & Rabbit Polyclonal & $1: 200$ & No PT & $4^{\circ} \mathrm{C} \mathrm{ON}$ \\
MyoD & 5.8A & Dako & Mouse monoclonal IgG & $1: 50$ & EDTA 20m & $4^{\circ} \mathrm{C} \mathrm{ON}$ \\
\hline
\end{tabular}

anti-bodies used and their optimised protocols, subject to negative controls and used as outlined below with development of DAB chromagen (Vector Laboratories Ltd.) for analysis with haematoxylin counter staining.

\subsection{Protein Analysis}

Protein expression of CD34, pax7 and MyoD in both sample groups was quantified using the Western blot technique with the aforementioned specific primary antibodies probing for their particular antigens and detection via densitometry. $50 \mu \mathrm{ls}$ Homogenising buffer ( $25 \mathrm{mM}$ Tris/HCl pH = 7.4, $1 \mathrm{mM}$ EDTA and $1 \mathrm{mM}$ EGTA) was added to each sample. The cell extracts were then centrifuged to pellet cell debris. Supernatants were added to $20 \mu \mathrm{ls}$ of $4 \times$ loading buffer (20\% sodium dodecyl Sulphate, $1 \mathrm{M}$ Tris/HCl pH 6.8, glycerol, mercaptoethanol, $0.2 \%$ bromophenol blue and deionised water) and heated in a water bath at $90^{\circ} \mathrm{C}$ for 5 minutes. Total protein (20 $\mu \mathrm{gs})$ and $10 \mu \mathrm{ls}$ of a molecular weight marking ladder were separated by SDS-PAGE electrophoresis with a current of $125 \mathrm{mV}$ over 90 minutes applied to $4 \%$ - 20\% Tris glycine polyacrylamide gels and transferred to nitrocellulose membrane (Hybond C-Extra membrane-Amersham Biosciences UK) by electroblotting using a transfer buffer (50 mls methanol, $20 \mathrm{mls} 25 \times$ Tris Glycine Buffer, made up to $500 \mathrm{mls}$ with deionised water) and a current of $35 \mathrm{mV}$ for 90 minutes. The membranes were blocked in 5\% milk in PBS/Tween for an hour followed by incubation with specific primary antibodies overnight at $4^{\circ} \mathrm{C}$. The following primary antibodies were diluted in $1 \times$ TRIS buffered saline to be used for immunoblotting at the following concentrations: pax7 (Aviva Biosystems) 1:2000, CD34 (Dako [1:2000] and MyoD (Dako) 1:1000.

The appropriate secondary horseradish peroxidase (HRP)-conjugated affinity purified goat anti-rabbit for pax7 and HRP-conjugated goat anti mouse for CD34/MyoD (Vector laboratories) was added to the membrane at the consecutive concentrations of 1:3000 and 1:2000 at room temperature for an hour. Over half an hour a TBS wash was applied every ten minutes and developed after the addition of Enhanced Chemiluminescence Kit, (Amersham Biosciences UK) to the membranes placed on autoradiographical film (ECL Hyperfilm, Amersham Biosciences UK). Quantification of the probed antigens was performed via a laser scanner and these bands were expressed in relative density units (RDU) according to the strength of the luminescence and represented in Figure 2.

\section{Results}

CD34 is well known to be expressed by both satellite cells and haematopoietic stem cells (HSCs). Pax7 is expressed by satellite cells alone. The combination of the two, co-localised, highlights quiescent satellite cells in sequential slides. MyoD is a marker of activated satellite cells [25]-[34].

Expression of pax7 was found to be markedly increased throughout the ischaemic muscle samples when compared to the control group samples. Not only was there a 2.4 fold increase in pax7 positively staining nuclei of satellite cells per field ( $\mathrm{p}<0.0001$ ), but it was noted that there was a clear difference in the pattern of expression seen by greater amounts of the brown DAB chromagen throughout the myofibrils. CD34 positive nuclei in ischaemic tissue were found to be increased by twofold, $(p<0.0001)$ when compared to control tissue. CD34 and pax7 positive cells were noted to be increased in ischaemic tissue when compared with control tissue (2.9× fold increase $p>0.0001 ; 95 \%$ CI). Figure 1: Serial sections from an ischaemic sample vs a control sample for pax7, CD34 and MyoD. Graphs c, f and i also show the mean number of positive nuclei/per five fields of each sample.

The over expression of pax7 and the increased CD34 seen in immunohistochemistry was then quantified via Western Blotting, the results are displayed in Figure 2. Conversely, while expression of MyoD in control tissue is scant, there is a significant decrease $\times 1.75(\mathrm{p}<0.0001)$ in ischaemic tissue compared to control. 


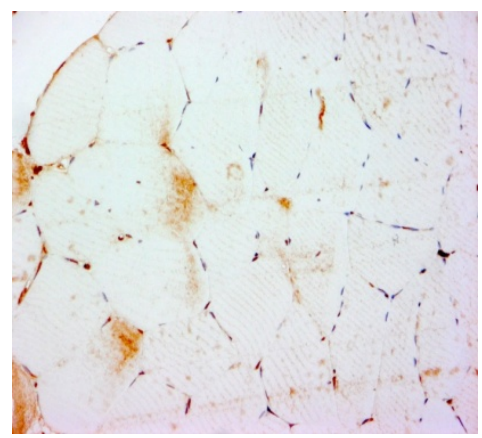

(a)

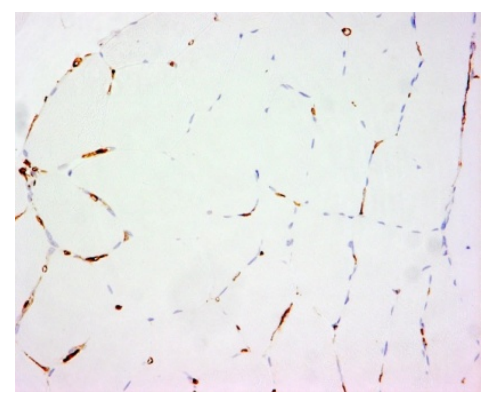

(d)

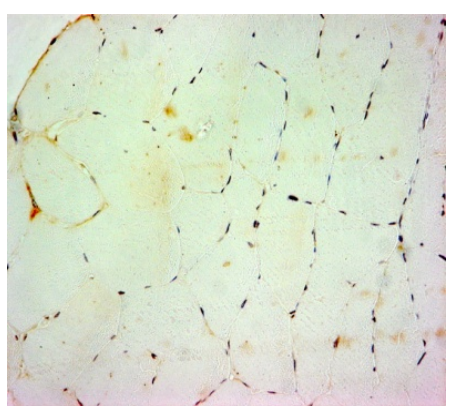

(g)

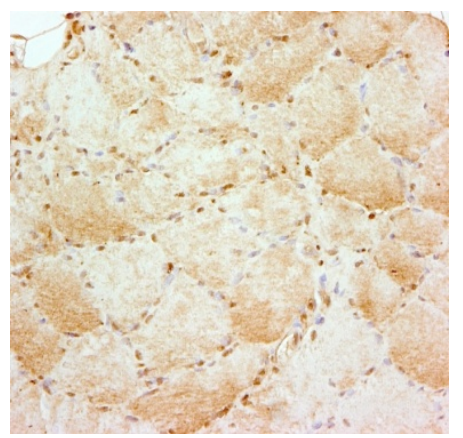

(b)

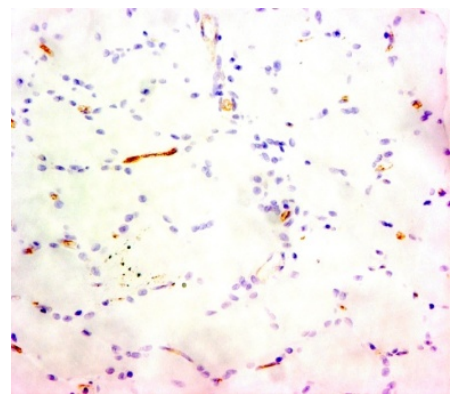

(e)

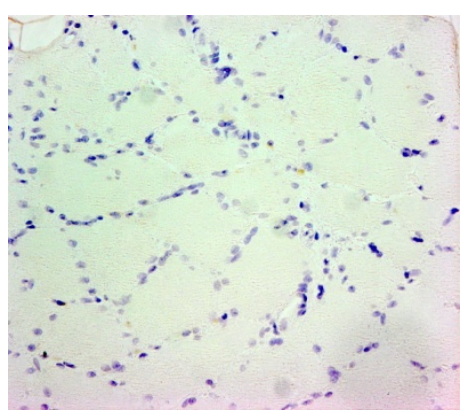

(h)

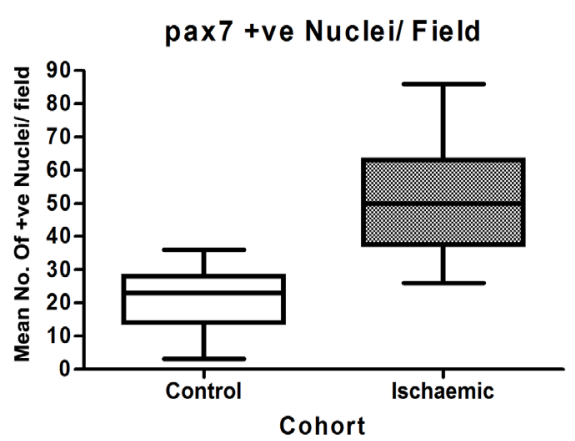

(c)

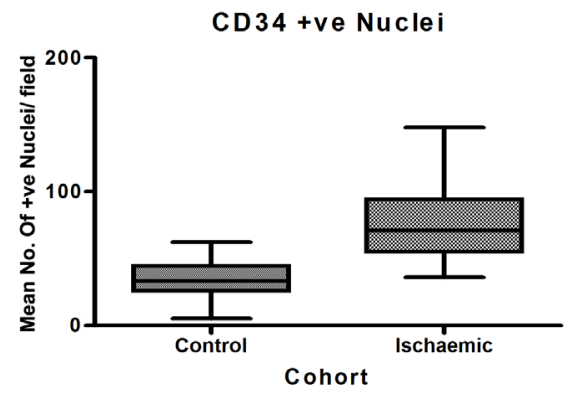

(f)

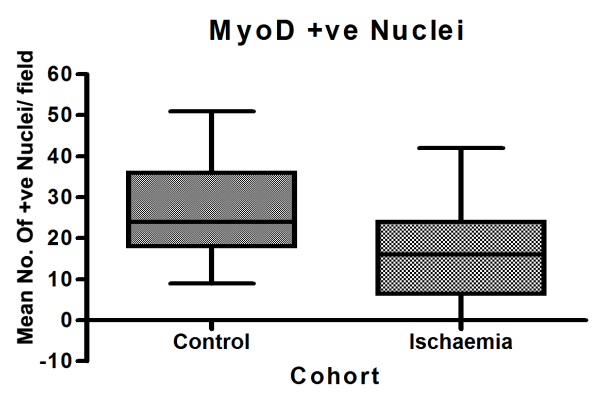

(i)

Figure 1. (a)-(i) pax7 expression in Control Muscle (b) pax7 expression in Ischaemic Muscle (200× magnification using DAB chromagen). There is over expression of pax7 as well as a $2.4 \times$ fold mean increase in positive staining cells throughout the ischaemic tissue $(\mathrm{p}<0.0001)$ represented in graph $1(\mathrm{c})$; Sequential Slides showing CD34 expression in (d); Control Vs (e) Ischaemic Tissue. There was $2 \times$ fold increase in mean CD34 positive cells $(p<0.0001)$ in the latter represented in (f); MyoD expression in control tissue (g) vs ischaemic tissue (h) and significantly reduced $1.75 \times(\mathrm{p}<0.0001)$ MyoD expression in ischaemic tissue, is represented in Graph (i).

Over expression of pax7 seems to have a negative effect on MyoD expression, seen in other studies [30] [37] [38].

Western blots of CD34, pax7 and MyoD were performed in frozen samples of both groups and expression of the proteins is represented below.

\section{Co-Localisation of CD34 and Pax7 Using Sequential Slides}

To confirm the activity of the numerous satellite cells observed, five random fields per sample on sequential slides were analysed and the number of cells staining for both CD34 and pax7 but not MyoD, which when colocalised, identified quiescent satellite cells. There was a mean of 6.3 cells staining positive for both CD34 and pax7 per $400 \times 300 \mu \mathrm{ms}$ field in control tissue compared with 18.46 cells per field in ischaemic tissue, a $2.9 \times$ fold increase ( $p<0.0001)$. Figure 3 represents the abundance of quiescent cells in ischaemic vs control tissue with representative stains of a single field with CD34/pax7 but an absence of MyoD. 


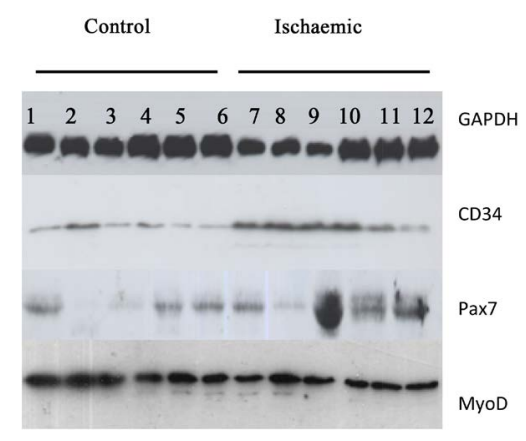

(a)

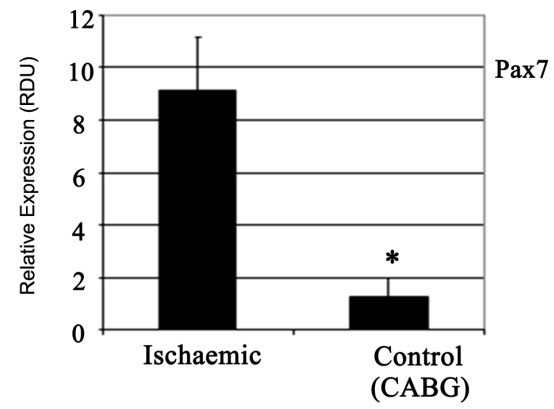

(c)

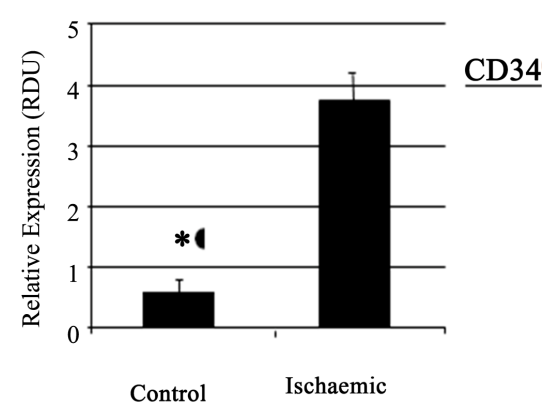

(b)

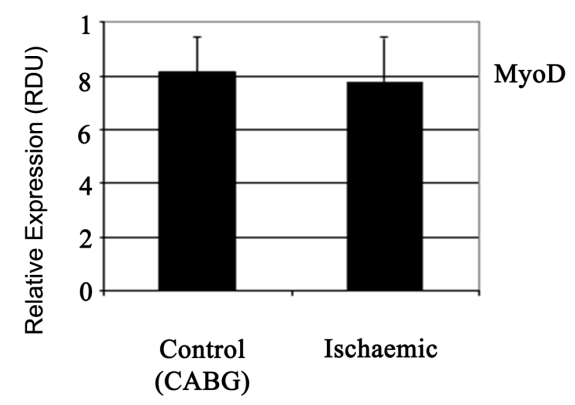

(d)

Figure 2. (a) Western blot analysis of protein expression with internal control via GAPDH. CD34, pax7 and MyoD were all analysed. A significant $(\mathrm{p}<0.05) 9 \times$ fold increase in pax7 expression (molecular weight $57 \mathrm{kDa}$ ) and a significant $2 \times$ fold increase in CD34 (molecular weight $116 \mathrm{kDa}, \mathrm{p}<0.05$ ) expression was demonstrated. The molecular weight of MyoD is $45 \mathrm{kD}$. There was no significant difference in MyoD expression in Control tissue when compared to Ischaemic tissue. A clean band was observed in both experiments when repeated. (b)-(d) Histograms showing Relative Density Units of CD34, pax7 and MyoD protein expression in Control vs Ischaemic muscle.

\section{Conclusions}

Satellite cells resident within skeletal muscle can be truly described as stem cells having a multipotent fate. It is these therefore that represent a source of autologous repair for damage caused by ischaemia. Pax7 is crucial to bestow a myogenic fate on satellite cells, myogenic precursors and MyoD is further required to commit myoblasts to a myogenic lineage [14] [39] [40]. In this study, an abundance of pax7 is seen throughout ischaemic tissue. Satellite cells expressing pax7 and CD34 and not myoD were present in ischaemic muscle in greater numbers. These represent the population of quiescent satellite cells or reserve cells, which are myogenic precursor cells and have the ability to form either myofibrils or satellite cells [17]. Their numbers as identified by pax7, MyoD and CD34 in this study are greatly increased in ischaemia but exist in an inactive state. It is likely that ischaemia induces proliferation and inhibits differentiation as evidenced by the reduction in cells expressing MyoD.

Activated satellite cells marked by pax7 and MyoD alone, are present but scarce in critical ischaemia. They may be the only cells which are responsible for renewing the satellite cell pool [30]. Derived from local skeletal muscle side population cells or from circulating haematopoietic cells, they become committed to a myogenic fate due to the high levels of pax7 present rather than to replenish the satellite cell pool. Other groups have found, in the damaged or denervated muscle of rodents at least, that MyoD and myogenin accumulation is prevalent [40]. Interestingly, this was not observed in this present study. CLI induced damage in adult human skeletal muscle significantly decreased in protein expression in MyoD.

\section{Discussion}

The muscle regulatory factors (MRFs), including MyoD, are able to dictate a skeletal muscle phenotype to non-specific progenitor cells. Proliferating myoblasts express myoD and myf5 in their cytoplasm before the 


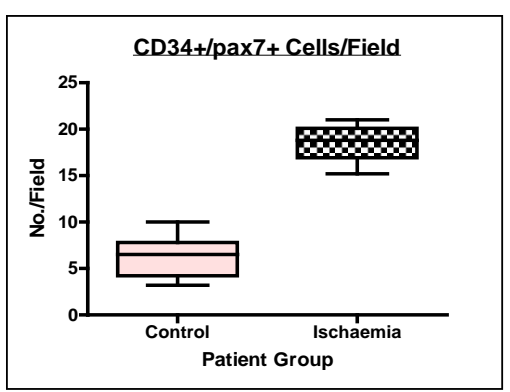

(a)

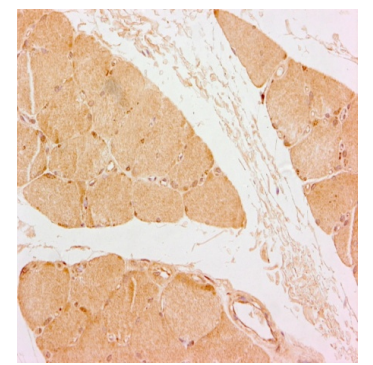

(c)

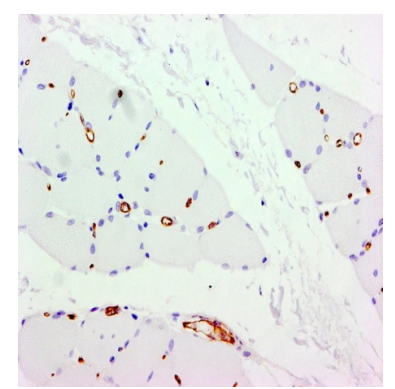

(b)

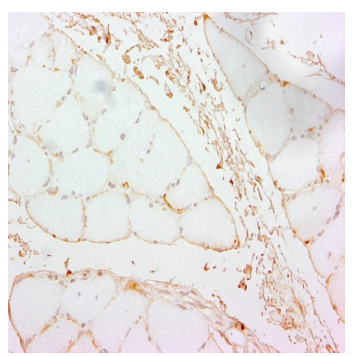

(d)

Figure 3. (a) Colocalisation of CD34 and pax7 indicate the mean number of quiescent satellite cells per five fields of control vs ischaemic tissue as determined through analysis of serial sections of muscle showing an abundance of co-localised CD34+/ pax7+/MyoD- cells in ischaemic tissue; $2.9 \times$ fold more ( ${ }^{*} \mathrm{p}<0.0001,95 \% \mathrm{CI}$ ); (b) Section of MyoD +ve gastrocnemius sample 400×; (c) Sequential slide demonstrating pax7 expression; and (d) Sample of CD34. Interestingly, this ischaemic sample showed rare positivity for all markers, indicating active satellite cell activity. (b)-(d) show one field analysed via sequential slides from a single patient to determine the frequency of positive antigen expression in ischaemic tissue compared to control tissue. All immunohistochemical analysis was performed using DAB chromagen.

stage of differentiation and those satellite cells differentiating into myofibres or satellite cells nuclei express MyoD (37). Interestingly, MyoD was less abundant in CLI tissue. The up regulation of the MRFs then leads to the exit of either the myoblasts or satellite cells from the cell cycle; myogenin is expressed and perpetuates the process of differentiation [33] [41]. Pax7 over expression seen here in CLI is similar to that reported by Enns and Tidus [37] and others [25] [30] which caused proliferation and inactivation of satellite cells but not their differentiation due to inhibition of MyoD [38]. Such activity prevents exit from the cell cycle which is required for cellular differentiation [41]. The process of myogenesis in adult ischaemic tissue may be incomplete as while satellite cells increase in number, these are generally not activated cells and cannot achieve maturity or differentiation [42].

Further work to elucidate the pathway that activates and causes the proliferation of quiescent satellite cells into myoblasts or renews the population of these active myogenic precursors would be the next logical step. The processes required stimulating the mesodermal progenitor cells to produce satellite cells, or those required to activate the numerous resident myogenic precursor cells will be crucial in combating the poor response of myogenic repair and regeneration seen in critical limb ischaemia. They may also serve as a source of stem cells which can contribute to new vessel, muscle and even nerve growth [16] [39] [40] [43]-[45].

\section{References}

[1] Schroeder, T.V. (2000) The TASC Supplement-International Recommendations for Management of Peripheral Arterial Disease. European Journal of Vascular and Endovascular Surgery, 19, 563. http://dx.doi.org/10.1053/ejvs.2000.1159

[2] Dormandy, J.A. and Rutherford, R.B. (2000) Management of Peripheral Arterial Disease (PAD). TASC Working Group. TransAtlantic Inter-Society Consensus (TASC). Journal of Vascular Surgery, 31, S1-S296.

[3] Loscalzo, J. (2001) Nitric Oxide Insufficiency, Platelet Activation and Arterial Thromosis. Circulation Research, 88, 756-762. http://dx.doi.org/10.1161/hh0801.089861 
[4] Jennische, E. (1985) Ischaemia-Induced Injury in Glycogen-Depleted Skeletal Muscle. Selective Vulnerability of FGFibres. Acta Physiologica Scandinavica, 125, 727-734. http://dx.doi.org/10.1111/j.1748-1716.1985.tb07776.x

[5] Regensteiner, J.G., Wolfel, E.E., Brass, E.P., Carry, M.R., Ringel, S.P., Hargarten, M.E., et al. (1993) Chronic Changes in Skeletal Muscle Histology and Function in Peripheral Arterial Disease. Circulation, 87, 413-421. http://dx.doi.org/10.1161/01.CIR.87.2.413

[6] Hedberg, B., Angquist, K.A., Henriksson-Larsen, K. and Sjostrom, M. (1989) Fibre Loss and Distribution in Skeletal Muscle from Patients with Severe Peripheral Arterial Insufficiency. European Journal of Vascular and Endovascular Surgery, 3, 315-322. http://dx.doi.org/10.1016/S0950-821X(89)80067-2

[7] Serrano, A.L., Pérez, M., Lucía, A., Chicharro, J.L., Quiroz-Rothe, E. and Rivero, J.L. (2001) Immunolabelling, Histochemistry and in Situ Hybridisation in Human Skeletal Muscle Fibres to Detect Myosin Heavy Chain Expression at the Protein and mRNA Level. Journal of Anatomy, 199, 329-337. http://dx.doi.org/10.1046/j.1469-7580.2001.19930329.x

[8] Gosker, H.R., van Mameren, H., van Dijk, P.J., Engelen, M.P.K.J., van der Vusse, G.J., Wouters, E.F.M. and Schols, A.M.J.W. (2002) Skeletal Muscle Fibre-Type Shifting and Metabolic Profile in Patients with Chronic Obstructive Pulmonary Disease. European Respiratory Journal, 19, 617-625. http://dx.doi.org/10.1183/09031936.02.00762001

[9] McGuigan, M.R., Bronks, R., Newton, R.U., Sharman, M.J., Graham, J.C., Cody, D.V., et al. (2001) Muscle Fiber Characteristics in Patients with Peripheral Arterial Disease. Medicine \& Science in Sports \& Exercise, 33, 2016-2021. http://dx.doi.org/10.1097/00005768-200112000-00007

[10] Slavin, G., Sowter, C., Ward, P., et al. (1982) Measurements of Striated Muscle Fibre Diameters Using Interactive Computer Aided Microscopy. Journal of Clinical Pathology, 35, 12568-12571. http://dx.doi.org/10.1136/jcp.35.11.1268

[11] Sant'ana Pereira, J.A., Wessels, A., Nijtmans, L., Moorman, A.F. and Sargeant, A.J. (1995) New Method for the Accurate Characterization of Single Human Skeletal Muscle Fibres Demonstrates a Relation between mATPase and MyHC Expression in Pure and Hybrid Fibre Types. Journal of Muscle Research and Cell Motility, 16, 21-34. http://dx.doi.org/10.1007/BF00125307

[12] Allbrook, D. (1981) Skeletal Muscle Regeneration. Muscle \& Nerve, 4, 234-245. http://dx.doi.org/10.1002/mus.880040311

[13] Zammit, P. and Beauchamp, J. (2001) The Skeletal Muscle Satellite Cell: Stem Cell or Son of Stem Cell? Differentiation, 68, 193-204. http://dx.doi.org/10.1046/j.1432-0436.2001.680407.x

[14] Hawke, T.J. and Garry, D.J. (2001) Myogenic Satellite Cells: Physiology to Molecular Biology. Journal of Applied Physiology, 91, 534-551.

[15] Pagani, F.D., DerSimonian, H., Zawadzka, A., Wetzel, K., Edge, A.S.B., Jacoby, D.B., Dinsmore, J.H., Wright, S., Aretz, T.H., Eisen, H.J. and Aaronson, K.D. (2003) Autologous Skeletal Myoblasts Transplanted to Ischemia-Damaged Myocardium in Humans. Journal of the American College of Cardiology, 41, 879-888. http://dx.doi.org/10.1016/S0735-1097(03)00081-0

[16] Arsic, N., Mamaeva, D., Lamb, N.J. and Fernandez, A. (2008) Muscle Derived Stem Cells Isolated as Non-Adherent Population Give Rise to Cardiac, Skeletal Muscle and Neural Lineages. Experimental Cell Research, 314, 1266-1280.

[17] Yoshida, N., Yoshida, S., Koishi, K., Masuda, K. and Nabeshima, Y.-I. (1998) Cell Heterogeneity upon Myogenic Differentiation Down-Regulation of MyoD and Myf-5 Generates "Reserve Cells”. Journal of Cell Science, 111, 769779.

[18] Collins, C.A., Olsen, I., Zammit, P.S., Heslop, L., Petrie, A., Partridge, T.A., et al. (2005) Stem Cell Function, Self-Renewal, and Behavioral Heterogeneity of Cells from the Adult Muscle Satellite Cell Niche. Cell, 122, 289-301. http://dx.doi.org/10.1016/j.cell.2005.05.010

[19] Minguell, J.J., Erices, A. and Conget, P. (2001) Mesenchymal Stem Cells. Experimental Biology and Medicine, 226, 507-520.

[20] Cassano, M., Quattrocelli, M., Crippa, S., Perini, I., Ronzoni, F. and Sampaolesi, M. (2009) Cellular Mechanisms and Local Progenitor Activation to Regulate Skeletal Muscle Mass. Journal of Muscle Research and Cell Motility, 30, 243253. http://dx.doi.org/10.1007/s10974-010-9204-y

[21] Ballas, C.B., Zielske, S.P. and Gerson, S.L. (2002) Adult Bone Marrow Stem Cells for Cell and Gene Therapies: Implications for Greater Use. Journal of Cellular Biochemistry, 85, 20-28. http://dx.doi.org/10.1002/jcb.10127

[22] Pugh, C.W. and Ratcliffe, P.J. (2003) Regulation of Angiogenesis by Hypoxia: Role of the HIF System. Nature Medicine, 9, 677-684.

[23] Xia, J.H., Xie, A.N., Zhang, K.L., Xu, L. and Zheng, X.Y. (2006) The Vascular Endothelial Growth Factor Expression and Vascular Regeneration in Infarcted Myocardium by Skeletal Muscle Satellite Cells. Chinese Medical Journal, 119, 
117-121.

[24] Hill, M., Wernig, A. and Goldspink, G. (2003) Muscle Satellite (Stem) Cell Activation during Local Tissue Injury and Repair. Journal of Anatomy, 203, 89-99. http://dx.doi.org/10.1046/j.1469-7580.2003.00195.x

[25] Zammit, P.S., Relaix, F., Nagata, Y., Perez Ruiz, A., Collins, C.A., Partridge, T.A. and Beauchamp, J.R. (2006) Pax7 and Myogenic Progression in Skeletal Muscle Satellite Cells. Journal of Cell Science, 119, 1824-1832. http://dx.doi.org/10.1242/jcs.02908

[26] Cornelison, D.D. and Wold, B.J. (1997) Single-Cell Analysis of Regulatory Gene Expression in Quiescent and Activated Mouse Skeletal Muscle Satellite Cells. Developmental Biology, 191, 270-283. http://dx.doi.org/10.1006/dbio.1997.8721

[27] McFarlane, C., Hennebrya, A., Thomas, M., Plummer, E., Ling, N., Sharma, M. and Kambadur, R. (2008) Myostatin Signals through Pax7 to Regulate Satellite Cell Self-Renewal. Experimental Cell Research, 314, 317-329.

[28] Pawlikowski, B., Lee, L., Zuo, J. and Kramer, R. (2009) Analysis of Human Muscle Stem Cells Reveals a Differentiation-Resistant Progenitor Cell Population Expressing Pax7 Capable of Self Renewal. Developmental Dynamics, 238, 138-149. http://dx.doi.org/10.1002/dvdy.21833

[29] Renault, V., Thornell, L.E., Eriksson, P.O., Butler-Browne, G. and Mouly, V. (2002) Regenerative Potential of Human Skeletal Muscle during Aging. Aging Cell, 1, 132-139. http://dx.doi.org/10.1046/j.1474-9728.2002.00017.x

[30] Olguin, H.C. and Olwin, B.B. (2004) Pax-7 Up-Regulation Inhibits Myogenesis and Cell Cycle Progression in Satellite Cells: A Potential Mechanism for Self-Renewal. Developmental Biology, 275, 375-388. http://dx.doi.org/10.1016/j.ydbio.2004.08.015

[31] Andros, V. and Walsh, K. (1996) Myogenin Expression, Cell Cycle Withdrawal, and Phenotypic Differentiation Are Temporally Separable Events That Precede Cell Fusion upon Myogenesis. The Journal of Cell Biology, 132, 657-666. http://dx.doi.org/10.1083/jcb.132.4.657

[32] Beauchamp, J.R., Heslop, L., Yu, D.S., Tajbakhsh, S., Kelly, R.G., Wernig, A., et al. (2000) Expression of CD34 and Myf5 Defines the Majority of Quiescent Adult Skeletal Muscle Satellite Cells. The Journal of Cell Biology, 151, 12211234. http://dx.doi.org/10.1083/jcb.151.6.1221

[33] Di Carlo, A., De Mori, R., Martelli, F., Pompilio, G., Capogrossi, M.C. and Germani, A. (2004) Hypoxia Inhibits Myogenic Differentiation through Accelerated MyoD Degradation. The Journal of Biological Chemistry, 279, 1633216338.

[34] de la Serna, I.L., Roy, K.A. and Imbalzano, A.N. (2001) MyoD Can Induce Cell Cycle Arrest but Not Muscle Differentiation in the Presence of Dominant Negative SWI/SNF Chromatin Remodeling Enzymes. The Journal of Biological Chemistry, 276, 41486-41491. http://dx.doi.org/10.1074/jbc.M107281200

[35] Askew, C.D., Green, S., Walker, P.J., Kerr, G.K., Green, A.A., Williams, A.D., et al. (2005) Skeletal Muscle Phenotype Is Associated with Exercise Tolerance in Patients with Peripheral Arterial Disease. Journal of Vascular Surgery, 41, 802-807. http://dx.doi.org/10.1016/j.jvs.2005.01.037

[36] Lexell, J. and Taylor, C.C. (1989) Variability in Muscle Fibre Areas in Whole Human Quadriceps Muscle: How to Reduce Sampling Errors in Biopsy Techniques. Clinical Physiology, 9, 333-343. http://dx.doi.org/10.1111/j.1475-097X.1989.tb00987.x

[37] Enns, D.L. and Tiidus, P.M. (2008) Estrogen Influences Satellite Cell Activation and Proliferation Following Downhill Running in Rats. Journal of Applied Physiology, 104, 347-353. http://dx.doi.org/10.1152/japplphysiol.00128.2007

[38] Hyatt, J.P.K., McCall, G.E., Kander, E.M., Zhong, H. and Roy, R.R. (2008) Pax3/7 Expression Coincides with MyoD during Chronic Skeletal Muscle Overload. Muscle \& Nerve, 38, 861-866.

[39] Dedkov, E.I., Borisov, A.B., Wernig, A. and Carlson, B.M. (2003) Aging of Skeletal Muscle Does Not Affect the Response of Satellite Cells to Denervation. Journal of Histochemistry Cytochemistry, 51, 853-863. http://dx.doi.org/10.1177/002215540305100701

[40] Seale, P., Sabourin, L., Girgis-Gabardo, A., Mansouri, A., Gruss, P. and Rudnicki, M.A. (2000) Pax7 Is Required for the Specification of Myogenic Satellite Cells. Cell, 102, 777-786. http://dx.doi.org/10.1016/S0092-8674(00)00066-0

[41] Lassar, A.B., Skapek, S.X. and Novitch, B. (1994) Regulatory Mechanisms That Coordinate Skeletal Muscle Differentiation and Cell Cycle Withdrawal. Current Opinion in Cell Biology, 6, 788-794.

[42] Gregory, M.A. and Mars, M. (2004) Mobilisation of Satellite Cells Following Ischaemia and Reperfusion in Primate Skeletal Muscle. Sports Medicine, 16, 17-24.

[43] Shireman, P. (2007) The Chemokine System in Arteriogenesis and Hind Limb Ischemia. Journal of Vascular Surgery, 45, A48-A56. http://dx.doi.org/10.1016/j.jvs.2007.02.030

[44] Lasala, G.P., Silva, J.A., Gardner, P.A. and Minguell, J.J. (2010) Combination Stem Cell Therapy for the Treatment of Severe Limb Ischemia: Safety and Efficacy Analysis. Angiology, 61, 551-556. 
http://dx.doi.org/10.1177/0003319710364213

[45] Lu, D.B., Chen, B., Liang, Z.W., Deng, W.Q., Jiang Y.Z.,Li, S.F., Wu, Q.N., Zhang, Z.H., Xie, B. and Chen, S.H. (2011) Comparison of Bone Marrow Mesenchymal Stem Cells with Bone Marrow-Derived Mononuclear Cells for Treatment of Diabetic Critical Limb Ischemia and Foot Ulcer: A Double-Blind, Randomized, Controlled Trial. Diabetes Research and Clinical Practice, 92, 26-36. http://dx.doi.org/10.1016/j.diabres.2010.12.010 